\title{
RESPONSIVENESS OF HOTEL WEBSITES: AN EXAMPLE FROM RZESZÓW AND ITS SURROUNDINGS
}

\author{
KRZYSZTOF SZPARA, ${ }^{1}$ LIUDMYLA PROCHKO ${ }^{2}$ MARCIN KOZAK ${ }^{3}$
}

\author{
1 University of Information Technology and Management in Rzeszów \\ Faculty of Medicine \\ e-mail: kszpara@wsiz.rzeszow.pl \\ 2 Careers Ninja \\ e-mail: lucy@careers.ninja \\ 3 University of Information Technology and Management in Rzeszów \\ Faculty of Administration and Social Sciences \\ e-mail:mkozak@wsiz.rzeszow.pl
}

\section{\begin{tabular}{l|l} 
JEL CODES & L83, L84, L86
\end{tabular} \\ KEYWORDS mobile devices, Internet, booking}

ABSTRACT The internet services market in tourism is developing intensively. Among factors affecting the quality of hotel services, modern information technologies play an important role, so hotels need to adapt to this dynamically changing virtual environment. Since more and more Internet users use mobile devices, hotels should make their websites work with such devices; in other words, they should make them responsive. Responsive websites smoothly adapt to changes in browser size and screen resolution of all types of devices, both desktop and mobile. A site designed in such a way makes it easier to read content and navigate irrespective of the device used.

The aim of the study is to analyze the state of adaptation of hotel websites in Rzeszów and its surroundings to mobile devices. The results show that in 2016 many hotels did not have websites designed for mobile devices. Thus, there is a need to invest in websites compatible with mobile devices. Thanks to responsive websites, hotels will be more visible on the Internet and thereby easier to reach for potential customers.

\section{Introduction}

The market of internet services in tourism has been developing intensively. This can be seen in the studies conducted in 2006 and 2013 by Biełuszko (2014) who observed clear changes in the market, such as:

- an increasing number of ways to promote hotel services on the Internet, 
- an increasing degree of market globalization manifesting itself in the presentation of offers of some international businesses even in 90 languages,

- a possibility for a hotel to directly manage its offers,

- the appearance of numerous and very popular Internet comparison services.

Hospitality industry is one of the most important industries of the tourism sector, and an important factor affecting the quality of hotel services is the use of modern information technologies. They allow hotel entrepreneurs to obtain, process, analyze, and exchange information necessary to conduct effective business operations (Szostak, 2008). These days, most hotels invisible online are almost invisible in general.

These days, it is the Internet that offers the most popular form of communication with recipients. It allows bilateral communication; constant access to information; searching, collecting and organizing data; and making transactions - all of these at low unit costs (Orfin, 2013). A good website is thus a necessity in the modern world of hotel services, a necessity without which most hotels are doomed to extinction.

More and more Internet users - tourists are no exception - use mobile devices. At the beginning of 2018, the number of mobile phone users amounted to 5.135 billion globally, an annual increase of $4 \%$. Already $68 \%$ of the population uses such devices (Majchrzyk, 2018). Thus, for a website to be available to as many users as possible, it should be responsive: RWD (Responsive Web Design) websites render well regardless of the device and screen size (Gardner, 2011).

Dedicated exclusively to mobile devices, mobile websites are separate websites (with a different address), lighter and faster, which load automatically (without user's action) after the original website detects a mobile device trying to open it. Responsive websites do not require such redirection. They do not need two separate websites, instead adapting themselves to a browser, screen resolution, and a device, whether desktop or mobile (E-hotelarz, 2015). A site designed in such a way makes it easier to read its content and navigate through it.

This study aims to analyze whether hotels located in Rzeszów and its surroundings are responsive, so whether they are mobile-device-friendly.

\section{Mobile operating systems and booking portals for accommodation}

Not long ago, websites in the hotel industry mainly aimed at presenting basic information about the hotel. Recently, a hotel website should also work as a virtual seller whose task is to provide information, encourage reservations, and enable transactions in real time (Litvin Goldsmith, R.E., Pan, 2008; Wang, Law, Guillet, Hung, Fong, 2015). Now, however, even these functionalities are not enough: more and more often people - tourists included - are using mobile devices, and thus a hotel website should not be repellent for the users who visit it on their mobile devices. In 2014, $53 \%$ of inspirations related to travel began on mobile devices, according to Frits van Paasschen, President and CEO of Starwood Hotels \& Resorts (Stuchać gości..., 2014). According to Criteo's Travel Insights Report, those travel companies who had their dedicated mobile applications saw that $41 \%$ of their bookings take place on mobile devices in the fourth quarter of 2016 and $60 \%$ in 
the same period in 2017, quite an impressive increase. Online travel agents also note the increasing use of mobile devices, with $45 \%$ of the bookings being made with a smartphone or tablet (up to $80 \%$ in 2018).

In recent years, the market of mobile operating systems has been rapidly changing (fig. 1). In 2010, it was fragmented with two dominating giants (Black Berry and Symbian) and several smaller ones (e.g. Bada, the experimental Samsung system). In 2016, only two players counted but different ones: Android (84.8\%) and iOS (14.4\%) on iPhones, the remaining ones being used mainly on old smartphones and accounting for only $0.8 \%$ of the market. Android has been constantly strengthening its position on the market ever since, its share in 2017 amounting to $85.9 \%$. It is currently the most affordable platform on which cheap devices operate, many of which are still in use (Majchrzyk, 2018).

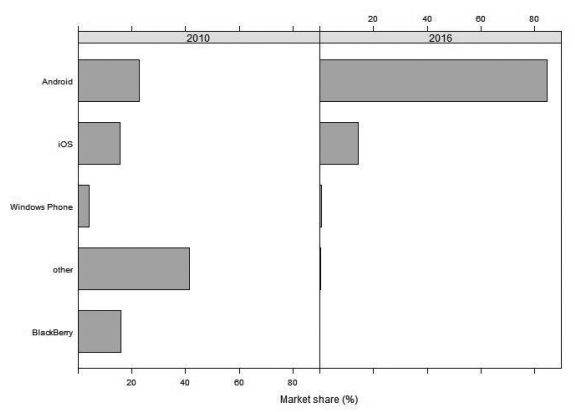

Figure 1. Market share of global mobile operating systems sold to end users

Source: https://mobirank.pl/2018/05/12/udzial-mobilnych-systemow-operacyjnych-na-swiecie-4q-2017/ (24.09.2018).

Websites offer hoteliers a lot of interesting information about their users. One such piece of information is what kind of devices the users use. Such information can help to decide to rebuild a website, for instance when many website guests use mobile devices and the website is not mobilefriendly (Marek, 2014).

In June 2013, the ARC Rynek i Opinia Research Institute conducted an expert study aimed at analyzing the brand awareness of hotel reservation systems in Poland. The survey results covered ten portals: Booking.com, Trivago.pl, HRS.pl, Rezerwuje.pl, Hotele.pl, Hotels.com, Expedia.com, OdkryjPolske.pl, Kayak.com, and StayPoland.pl. The experts from the Interaktywnie.com portal were asked to express their opinion as to whether the websites recognition went hand in hand with their usefulness. To assess website usefulness, the experts evaluated the website method and time of operation, graphic design, quality and form of the information, general impression after using the website, and additional functionalities, including the mobile version of the website. Among the studied websites, Booking.com received the highest score (Interaktywnie.com, 2013).

A study conducted in 2016 at 1400 hotels by the German Hotel Association (Hotelverband Deutschland - IHA) in cooperation with the Institute of Tourism at Westschweiz Wallis Higher Vocational School showed that $25.2 \%$ of overnight accommodations in Germany were purchased 
through booking portals. Over $95 \%$ of the market share belonged to three companies, namely, Booking.com (54.7\%), HRS (30.4\%) and Expedia (10.8\%) (Szypuła, 2017).

A study by HRS, a leading hotel booking portal in Europe, shows that hotel reservations are more and more often made using mobile applications. In 2015, nearly one in five overnight accommodations was booked using a mobile device. The survey showed that $19.6 \%$ of respondents had made at least one such reservation, and about $13 \%$ - most of whom were in the age range of 30-49did so regularly. A market study by eResult showed that private travelers used mobile solutions almost as often (18.4\%) as did business travelers (21.2\%), the ease of booking being the reason the respondents offered as an explanation to the use of a mobile device (E-hotelarz, no publication year).

\section{Study areg}

Located in south-eastern Poland, on the Wisłok River, Rzeszów is the capital of Podkarpackie Voivodeship. It is an important administrative, economic, cultural and academic center in the region. Its good transport accessibility is due to the location near the A4 motorway and the S19 expressway (still under construction), important railway lines, and Rzeszów-Jasionka Airport. In 2016, Rzeszów occupied an area of $117 \mathrm{~km}^{2}$ and was inhabited by 187,422 people (Statystyczne Vademecum Samorządowca, 2017).

In 2015, there were 39 tourist accommodation establishments in Rzeszów, 2,914 beds altogether. Throughout the year, 220,718 people used them, including 60,380 foreign tourists. In total, 322,236 overnight accommodations were registered, including 81,500 accommodation for foreigners. Among the foreign tourists using the tourist accommodation establishments, 33.4\% were from Ukraine, 15.7\% from Germany, and 6.8\% from Israel (Turystyka..., 2016).

Among various tourist accommodation establishments, hotels play a key role. In 2016, 30 hotels operated in the city: one five-star (Hotel Bristol - Tradition \& Luxury), five four-star, thirteen three-star, seven two-star, two one-star, and two under categorization (Bank Danych Lokalnych). In addition, a dozen or so facilities are located in the suburbs, some of which of very high standards (e.g. Blue Diamond Active Spa Hotel).

\section{Methods}

Conducted from June to September 2016, this research assessed the responsiveness of hotel websites in and around Rzeszów. In particular, the study focused on whether the websites were adapted to mobile devices.

The study included 28 hotels representing the whole range of standards. We analyzed their websites using Google's PageSpeed Insights tool, which shows the speed of a website on computers and mobile devices, on a scale from 1 to 100, and the Google-Mobile-Friendly tool which assesses whether a website is adapted to mobile devices.

We will use the scoring interpretation suggested by the PageSpeed Insights documentation (About PageSpeed Insights, 2018). According to this, a page is considered "good" when it scores at least 80 points: such a page "applies most performance, best practices and there is little headroom 
for further optimization." The score is "low" when it is below 60: such a page "is not optimized and there is fairly large headroom for optimization."

We supplemented the study with the direct analysis of hotel websites using an iPhone 6 smartphone. In its course, one of the co-authors (L.P.) opened websites of all hotels under research on the above-mentioned device and analyzed their aspects as being visually adapted to mobile devices, presence of easy-to-locate booking option, and easy access to basic information about the hotel.

\section{Results}

Even the fastest websites were not really fast, the highest score was below 90 PageSpeed Insights points. The fastest-running websites on computers (the score of over 80 points) had the following hotels (fig. 2): Best Western Plus Ferdynand***, Horizon***, Eden*, Falcon***, Grein***, and Prezydencki****. Websites of 11 hotels had low PageSpeed scoring (with fewer than 60 points), the slowest website (below 30 points) of Hotel Zimowit***. None of the websites, however, had a good score (at least 80 points) for mobile devices, and only three websites had at least 70 points on mobile devices, namely, Best Western Plus Ferdynand***, Falcon***, and Grein***. As many as 13 websites scored low (below 60 points) on mobile devices, and two others reached the boundary of 60 points. The slowest websites (scoring below 25 points) were those of Schanel Residence*** and Zimowit***. The median score was 56.5 on computers and 49.5 on smartphones.

The websites of all hotels but two (Hotel Classic and The Blue Diamond Active Spa) scored better on computers than on smartphones, quite likely due to their being designed at least a few years before the study. Back then, mobile devices played a minor role in booking - so, for a hotel, creating a responsive website was more of an innovation than a necessity.

The study also identified faults which should and those which could be improved (fig. 3). Among the elements indicated as necessary for improvement, the most frequent ones were the following: eliminating the JavaScript and CSS code blocking rendering from the part of the page visible on the screen ( $92.9 \%$ of the websites tested); using the browser's cache (71.4\%); optimizing images (32.1\%); including compression (14.3\%); reducing server response time (10.7\%); reducing JavaScript (7.1\%); using legible font sizes (7.1\%); changing window configuration (7.1\%); choosing the right size of the touch elements $(3.6 \%)$.

Among the elements that could be improved, the most frequent ones were the following: reducing JavaScript (71.4\%); reducing CSS (60.7\%); optimizing images (46.4\%); shortening the server response time (39.3\%); including compression (32.1\%); reducing HTML (28.6\%); using the browser's cache $(21.4 \%)$; prioritizing the visibility of content $(17.9 \%)$; avoiding redirection of landing pages (3.6\%); choosing appropriate sizes of touch elements (3.6\%); and avoiding the use of plugins $(3.6 \%)$. 


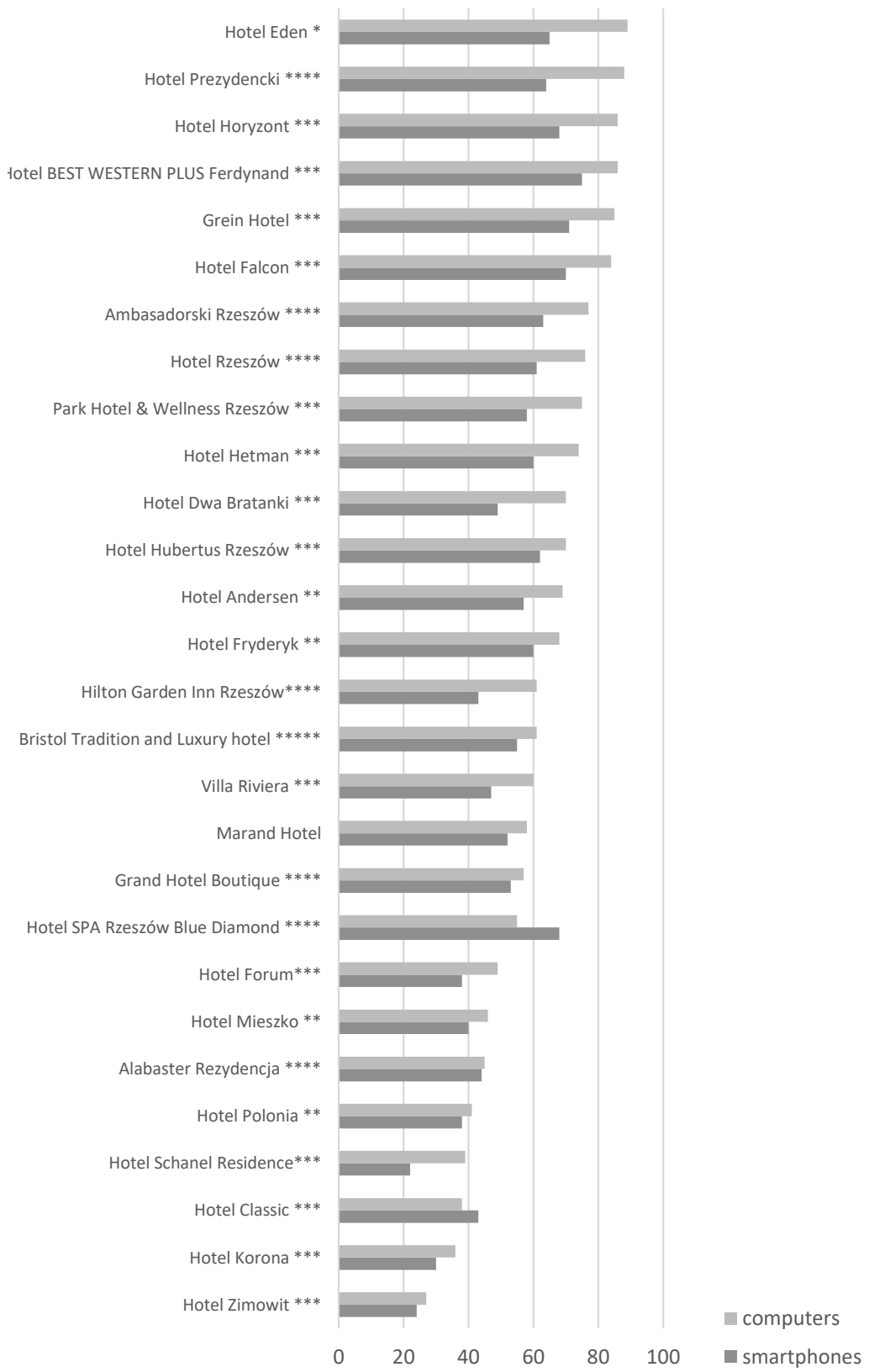

Figure 2. Loading speed of websites of the studied hotels from Rzeszów and its surroundings

Source: own study based on data obtained with PageSpeed Insights. 


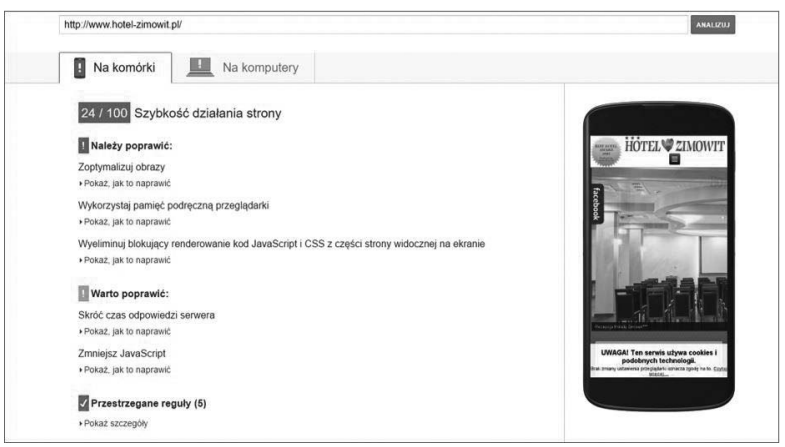

Figure 3. An example of a slow website: PageSpeed Insights for the Zimowit hotel on a mobile device Source: own study based on data obtained with PageSpeed Insights.

The test carried out on the mobile device showed that only ten hotels had reasonably useful pages. Unfortunately, most of the tested websites were neither adapted to mobile devices nor intuitive. Problems occurred both at the home page and after expanding the menu. For example, often the basic function "Book" was missing, and instead other - less useful - information appeared, often too much of it and taking too much space.

According to the test of compliance for mobile devices, carried out with Google's MobileFriendly Test, $53.6 \%$ of examined websites were well adapted. The most frequent comments for the websites that did not pass the test were as follows:

- links located too close to each other (100\% of the pages that were negatively rated),

- too small font hindering reading $(69.2 \%)$,

- working window not set for mobile devices (69.2\%),

- content wider than the screen (53.8\%),

- using incompatible plugins $(7.7 \%)$.

\section{Conclusions}

The results showed that in 2016 websites of most hotels located in Rzeszów and its surroundings were non-responsive. In order to keep pace with the changing world and the needs of potential guests, these hotels should consider investing in websites that are both user-friendly and compatible with mobile devices. Otherwise, they risk being marginalized in this fast-changing market.

People all over the world tend to use mobile devices more and more, and tourists are no exception to this rule. Indeed, mobile devices, especially smartphones, have affected the hospitality industry (Wang, Xiang, Low, Ki, 2016). These days, mobile phones are not just phones: they are smartphones, smart computers offering various information services that can be accessed whenever and wherever one has Internet access via Wi-Fi or a mobile network (Wang, Park, Fesenmaier, 2011).

Tourists need a quick and easy way to book accommodations anytime and from anywhere. These days, it is mobile devices that offer such service. One takes the smartphone from a pocket, 
and there it is: all the information a tourist needs to make a reservation. So hotels that disregard such needs disregard their potential clients, risking losing them forever.

A website is a hotel's showcase on the Internet. If it is unreadable, incomprehensible, difficult to use, or mobile-unfriendly, it is likely to repel most potential guests. Unfortunately, even highstandard hotels in 2016 had very unhelpful websites. Responsive websites could help them increase their visibility on the Internet and make them easier to reach for potential customers, which could have a major impact on both the use of accommodation in facilities and profits. Importantly, such investments are usually relatively low, given all the costs hotels have to incur.

\section{References}

About PageSpeed Insights (2018). Retrieved from: https://developers.google.com/speed/docs/insights/about (13.10.2018).

Bank Danych Lokalnych. GUS. Retrieved from: https://bdl.stat.gov.pl/BDL/dane/podgrup/tablica (13.10.2018).

Biełuszko, K. (2014). Rynek internetowych pośredników hotelowych w Polsce - zasady funkcjonowania i tendencje zmian. In: G. Gołębski. A. Niezgoda (eds.), Turystyka wobec zmian wspótczesnego świata. Zmiany, bariery, innowacje (pp. 212-224). Poznań: Wydawnictwo Uniwersytetu Ekonomicznego w Poznaniu.

E-hotelarz (2015). Strony mobilne czy responsywne, o co w tym chodzi? Retrieved from: https://www.e-hotelarz.pl/ $\mathrm{mht} / \mathrm{p}=30522(13.10 .2018)$.

E-hotelarz (no publication year). Rezerwacja hotelu - coraz częściej za pomoca aplikacji mobilnych. Retrieved from: http://www.e-hotelarz.pl/mht/?p=9808 (13.10.2018).

Gardner, B.S. (2011). Responsive web design: Enriching the user experience. Sigma Journal: Inside the Digital Ecosystem, $1(11), 13-19$.

Interaktywnie.com (2013). Najlepsze serwisy do rezerwacji hoteli. Retrieved from: https://interaktywnie.com/biznes/ newsy/oceny-serwisow/najlepsze-serwisy-do-rezerwacji-hoteli-246848?page=1 (13.10.2018).

Litvin, S.W., Goldsmith, R.E., Pan, B. (2008). Electronic word-of-mouth in hospitality and tourism management. Tourism Management, 3 (29), 458-468.

Majchrzyk, Ł. (2018). Udział mobilnych systemów operacyjnych na świecie (4Q 2017). Retrieved from: https://mobirank. pl/2018/05/12/udzial-mobilnych-systemow-operacyjnych-na-swiecie-4q-2017 (13.10.2018).

Marek, R. (2014). Wirtualny sprzedawca usług. Świat Hoteli. Retrieved from: http://data.axmag.com/data/201409/20140915/ U44451_F301746/FLASH/index.html (13.10.2018).

Orfin, K. (2013). Komunikacja marketingowa w turystyce i rekreacji. In: A. Panasiuk (ed.), Marketing w turystyce i rekreacji (pp. 265-289). Warsaw: Wydawnictwo Naukowe PWN.

Słuchać gości i oferować to czego oczekują (2014). Rozmowa Karoliny Stępniak z Fritsem van Paasschen [The interview of Karolina Stępniak with Frits van Paasschen]. Świat Hoteli 6, 14-16. Retrieved from: http://data.axmag.com/ data/201409/20140915/U44451_F301746/FLASH/index.html (13.10.2018).

Statystyczne Vademecum Samorządowca (2017). Urząd Statystyczny w Rzeszowie. Retrieved from: https://rzeszow.stat. gov.pl/vademecum/vademecum_podkarpackie/portrety_miast/miasto_rzeszow.pdf (13.10.2018).

Szostak, D. (2008). Hotelarstwo i gastronomia. In: A. Panasiuk (ed.), Gospodarka turystyczna (pp. 109-132). Warsaw. Wydawnictwo Naukowe PWN.

Szypuła, G. (2017). Portale zdominowały rezerwacje noclegów. Rzeczpospolita. Retrieved from: https://www.rp.pl/ Hotele/304259972-Portale-zdominowaly-rezerwacje-noclegow.html (13.10.2018).

Turystyka w województwie podkarpackim w latach 2014-2015 (2016). Rzeszów: Urząd Statystyczny w Rzeszowie.

Up to $80 \%$ of last-minute hotel bookings are now made on mobile devices (2018). Retrieved from: http://hotelmarketing. com/index.php/content/article/up_to_80_of_last_minute_hotel_bookings_are_now_made_on_mobile_devices (13.10.2018). 
Wang, D., Park, S., Fasenmaier, D.R. (2011). An examination of information services and smartphone applications, $16^{\text {th }}$ Graduate Students Research Conference 2011, Houston, Texas. Retrieved from: https://www.researchgate.net/ publication/268200092_An_Examination_of_Information_Services_and_Smartphone_Applications.

Wang, D., Xiang, Z., Law, R., Ki, T.P. (2016). Assessing Hotel-Related Smartphone Apps Using Online Reviews. Journal of Hospitality Marketing \& Management, 3 (25), 291-313. DOI: 10.1080/19368623.2015.1012282.

Wang, L., Law, R., Guillet, B.D., Hung, K., Fong, D.K.C. (2015). Impact of hotel website quality on online booking intentions: eTrust as a mediator. International Journal of Hospitality Management, 47, 108-115.

\section{RESPONSYWNOŚĆ STRON INTERNETOWYCH HOTELI. NA PRZYKŁADZIE RZESZOWA I OKOLIC}

SŁOWA KLUCZOWE

STRESZCZENIE urządzenia mobilne, Internet, rezerwacje

Rynek usług internetowych w turystyce intensywnie się rozwija. Wśród czynników wpływających na jakość usług hotelarskich ważną rolę odgrywają nowoczesne technologie informacyjne, dlatego hotele muszą się dostosować do tego dynamicznie się zmieniającego środowiska wirtualnego. Ponieważ coraz więcej użytkowników Internetu korzysta z urządzeń mobilnych, hotele powinny sprawić, aby ich witryny współpracowały z takimi urządzeniami; innymi słowy, powinny one być responsywne. Responsywne strony internetowe płynnie dostosowują się do zmian rozmiaru przeglądarki i rozdzielczości ekranu wszystkich typów urządzeń, zarówno desktopowych, jak i mobilnych. Strona zaprojektowana w taki sposób ułatwia czytanie treści i nawigację niezależnie od używanego urządzenia.

Celem badania jest analiza stanu dostosowania stron internetowych hoteli w Rzeszowie i jego okolicach do urządzeń mobilnych. Wyniki pokazują, że w 2016 r. wiele hoteli nie miało stron internetowych zaprojektowanych z myślą o urządzeniach mobilnych. Dlatego istnieje potrzeba inwestowania w strony internetowe kompatybilne z urządzeniami mobilnymi. Dzięki responsywnym stronom internetowym hotele będą bardziej widoczne w Internecie, dzięki czemu łatwiej dotrzeć do potencjalnych klientów. 